Research Articles

\title{
Nested PCR method for detection Toxoplasma gondii B1 gene in Cerebrospinal Fluid of HIV patients
}

\author{
Ryan Halleyantoro ${ }^{1}$, Yunilda Andriyani ${ }^{2}$, Ika Puspa Sari ${ }^{3}$, Agnes Kurniawan ${ }^{3 *}$ \\ ${ }^{1}$ Departement of Parasitology, Faculty of Medicine, Diponegoro University, Indonesia \\ ${ }^{2}$ Departement of Parasitology, Faculty of Medicine, Universitas Sumatera Utara, Indonesia \\ ${ }^{3}$ Departement of Parasitology, Faculty of Medicine, Universitas Indonesia, Indonesia
}

\section{Article Info}

History

Received : 08 May 2019

Accepted : 10 Oct 2019

Available : 31 Dec 2019

\begin{abstract}
Background: Toxoplasmosis is a disease caused by infection of Toxoplasma gondii which may cause a life-threatening condition in immunocompromised patients, for example, Toxoplasma encephalitis (TE). It is challenging to diagnose Toxoplasma as a cause of central nervous system (CNS) infection in HIV patient, so we need an alternative method, which is a PCR detection of Toxoplasma gondii B1 gene.

Objective: This research aimed to find association between PCR methods for Toxoplasma gondii B1 gene and anti-Toxoplasma $\mathrm{IgG}$ from cerebral spinal fluid patient HIV AIDS.

Methods: A cross-sectional study was conducted to Cerebrospinal fluid (CSF) samples of HIV patients with neurological symptoms to determine Toxoplasma gondii infection using nested PCR methods for the B1 gene and detection of anti-Toxoplasma IgG.

Results: 88 CSF samples from HIV patients tested using nested PCR showed 23 samples $(26,1 \%)$ were positive. Serologic test for IgG Toxoplasma showed 34 samples were positive $(28,6 \%)$. There was a significant correlation $(\mathrm{p}=0.000(<0.05)$ between PCR result and a serologic test for IgG Toxoplasma.

Conclusion: Nested PCR methods to detect B1 gene increased the accuracy of diagnosis for toxoplasma encephalitis.
\end{abstract}

Keywords: cerebrospinal fluid; Toxoplasma gondii; PCR; IgG anti Toxoplasma; HIV Permalink/ DOI: https://doi.org/10.14710/jbtr.v5i2.4840

\section{INTRODUCTION}

Toxoplasma gondii infection comes from the protozoan parasite, which is predicted to infect about one-third of the world's population. ${ }^{1}$ The prevalence of toxoplasmosis in Jakarta is estimated to reach $70 \% .^{2}$ In normal condition, $T$. gondii infection is asymptomatic, but in some immunocompromised individuals, a bradyzoite-containing cyst can rupture and reactivate the latent infection-causing toxoplasma encephalitis (TE) ${ }^{3}$ Toxoplasma encephalitis (TE) attacks the central nervous system (CNS), especially in patients with severe HIV infection, even though the incidence of this disease decreases because of antiretroviral drugs. It is predicted that about $10-50 \%$ of AIDS patients with toxoplasmosis will continue to be TE. ${ }^{4}$

\footnotetext{
* Corresponding author:

E-mail: akatmadja@yahoo.com (Agnes Kurniawan)
}

In Indonesia, TE is still the main CNS disorder in AIDS patients followed after Tuberculous meningitis. ${ }^{5}$

A definitive diagnosis of TE can be provided by brain biopsy and finding $T$. gondii tachyzoites. The examination is an invasive procedure and associated with a significant increase in morbidity and mortality. A tentative diagnosis of this disease only based on CNS signs and symptoms, the positive result of anti-T. gondii antibody and typical single lesions or multiple ringenhancing lesions in the brain detected by Computed Tomography (CT) and Magnetic Resonance Imaging (MRI). ${ }^{1,6}$ Disadvantages of serologic test for Toxoplasma were the serologic result of anti-Toxoplasma antibody should be interpreted carefully and it can be failed to detect anti-Toxoplasma antibody in the early phase of infection. ${ }^{7,8}$ Serologic test also unable to detect Toxoplasma infections in immunocompromised patients, 
because there is a disturbance in immunoglobulin production, where anti-Toxoplasma IgG only appear in $30 \%$ HIV patients with active toxoplasmosis, and only $2 \%$ shows positive for IgM., ${ }^{9,10}$

The molecular diagnosis using PCR for various clinical specimens become a powerful tool for detection of $T$. gondii DNA. ${ }^{9} 11$ The problem is the sensitivity of this technique is not yet established. ${ }^{7,12}$ The utilization of PCR for detecting $T$. gondii in CSF has been done. PCR can detect $T$. gondii DNA using primer for the $\mathrm{B} 1$ gene, which is frequently used and has remarkable sequence conservation $(99.5 \%)$ of the B1 gene. It also has been confirmed by analysis of DNA sequences from many clonal strains. ${ }^{9}$ Some studies found that PCR sensitivity to detect $\mathrm{B} 1$ gene is $83.3 \%$, and its specificity reached $95.7 \%{ }^{12}$, and another experiment shows $100 \%$ sensitivity and $94.9 \%$ specificity $^{13}$.

The aim of the present study is to find association between of PCR methods for Toxoplasma gondii B1 gene and anti-Toxoplasma IgG from cerebral spinal fluid patient HIV AIDS.

\section{MATERIALS AND METHODS}

This study was held in the Laboratory of Parasitology Faculty of Medicine Universitas Indonesia, November 2015 - January 2016. A cross-sectional study was performed to determine Toxoplasma gondii infection from cerebrospinal fluid (CSF) of HIV patients with neurological symptoms. The inclusion criteria were all cerebrospinal fluid samples of HIV patients with neurological symptoms available in the Laboratory of Parasitology Faculty of Medicine Universitas Indonesia. The sampling technique used in this study was consecutive sampling, which means every CSF was included as a sample until minimal samples were achieved.

\section{DNA isolation from CSF and Amplification of targeting DNA}

DNA from CSF samples were extracted using DNA mini kit the QIAGEN method with $80 \mu \mathrm{L}$ AE buffer. $T$. gondii was detected using B1 gene amplification. The amplification was performed individually in $20 \mu \mathrm{L}$ of reaction mixture containing $1 \mathrm{x}$ PCR buffer, $1.5 \mathrm{mM}$ $\mathrm{MgCl} 2,200 \mu \mathrm{M}$ each were dNTP (dATP, dGTP, dTTP, $\mathrm{dCTP}), 250 \mu \mathrm{M}$ for each primer, and $1.5 \mathrm{U}$ Taq polymerase. The other conditions were optimized carefully before the study was started. Primers used were the same primers as the previous study $^{14}$ in gene amplification, as seen below. which consisted of heating temperature at $95^{\circ} \mathrm{C}$ for 7 minutes. Denaturation step continued as heating the reaction to $95^{\circ} \mathrm{C}$ for 1 minute, annealing step at $48^{\circ} \mathrm{C}$ for 1 minute, and followed by extension by extension step in $72^{\circ} \mathrm{C}$ for 2 minutes, and repeated for 35 times/cycles. The reaction was ended at $72^{\circ} \mathrm{C}$ extension for 7 minutes.

Amplification result was separated using agarose gel electrophoresis in $0.5 \mathrm{x}$ TBE $(0.05 \mathrm{M}$ Tris Base, $0.05 \mathrm{M}$ borate acid, and $0.001 \mathrm{M} \mathrm{pH} 8.5$ EDTA) buffer and stained with SYBR green. Electrophoresis was run at 100 volts for 50 minutes, and then the result was viewed under UV light.

Each PCR reactions included one negative control (pure water) and one positive control (from DNA extraction of $T$. gondii tachyzoites).

\section{IgG anti-Toxoplasma Examination from CSF}

IgG anti-Toxoplasma examination uses the AntiToxoplasma gondii ELISA (IgG) EUROIMMUN TM kit (Cat number EI 2410-9601G, Lübeck, Germany) and follows the procedure listed in the kit.

\section{Statistical analysis}

The result of PCR was categorized as positive or negative, and the result of serologic titer for IgGToxoplasma was divided into three groups based on Derouin et al. ${ }^{15}$ Those groups were negative (<11IU), low titers $(\geq 11-150 \mathrm{IU})$ and high titers $(>150 \mathrm{IU})$. These two different methods to be statistically analyzes using ChiSquare test for trend.

\section{Ethical aspect}

Ethical approval for the study was obtained from The Ethics Committee of Faculty of Medicine, University of Indonesia, which approved all protocol in this study.

\section{RESULTS}

This study using CSF samples from HIV patients with neurological disorders for example meningitis. There were 88 CSF available from Parasitology Department Faculty of Medicine Universitas Indonesia for examination. As many as 49 samples came with clinical diagnosis i.e. Tuberculosis meningoencephalitis (TB ME, 46\%), Toxoplasma encephalitis or TB ME (28\%), Cryptococcus meningitis or TB ME (12\%) and no clinical diagnosis for the rest. The samples originated from $90 \%$ male and $5 \%$ female with age ranged 20 to 50 years old.

\begin{tabular}{lll}
\hline PCR Round & Forward PCR primers $\left(5^{\prime}, 3^{\prime}\right)$ & Reverse PCR primers $\left(5^{\prime}-3-\right)$ \\
\hline First & GGAACTGCATCCGTTCATGAG & GGCGACCAATCTGCGAATACACC \\
\hline Second & TGCATAGGTTGCAGTCACTG & TCTTTAAAGCGTTCGTGGTC \\
\hline
\end{tabular}

As many as $3 \mu$ l extracting DNA from CSF samples were added to the mixture to make the template for the first PCR round, followed by $2 \mu \mathrm{l}$ DNA results from the first PCR round was used as templates for the second PCR round. The reaction condition was modified from previous study to optimize the PCR condition. ${ }^{12}$ PCR steps to amplify target gene were: initialization step,

\section{PCR examination results.}

B1 gene detection using nested PCR method had shown that 23 out of 88 samples were positive. Positive results were characterized by obtaining a specific band of DNA Toxoplasma gondii at $131 \mathrm{bp}$ whereas negative result showed no band at all (Figure 1). 


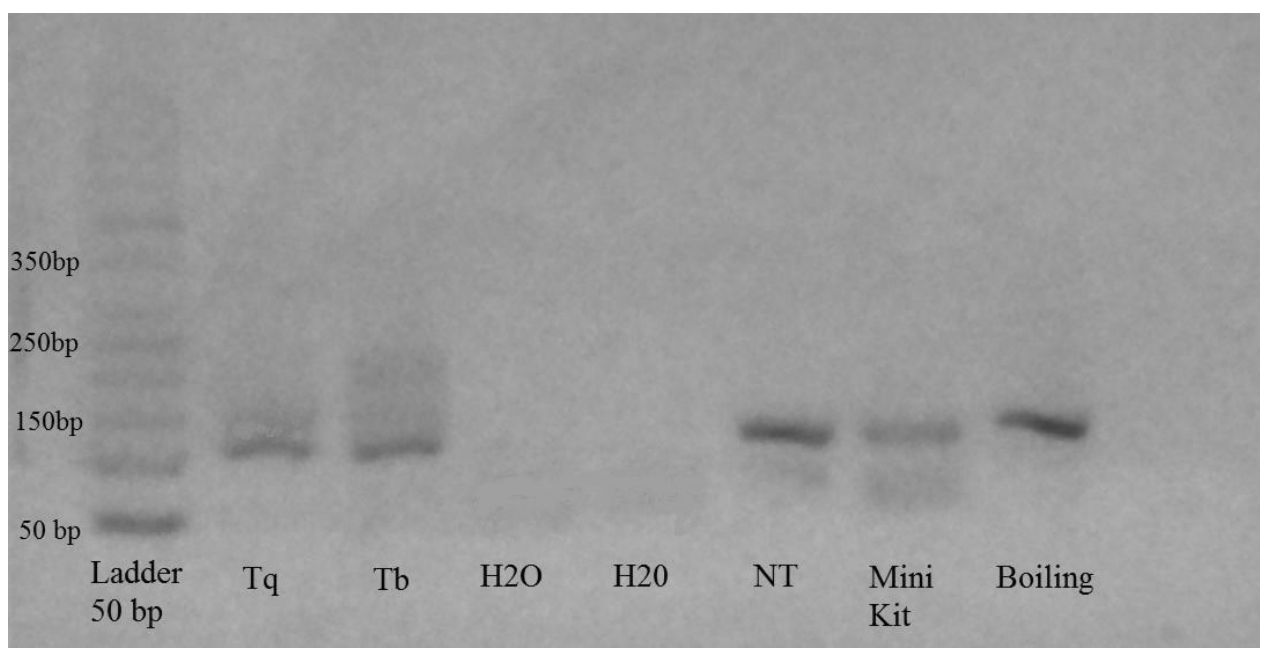

Figure 1. Optimization of DNA extraction results. From left to right: ladder 50bp, tachyzoites extraction using QIAGEN minikit method (Tq), boiling method for tachyzoites (Tb), negative control 1 (H20), negative control 2 (H20), direct method for CSF (NT), minikit method for CSF (Mini kit), boiling method for CSF (boiling)

Table 1. Comparison between PCR-based method and serologic test for IgG anti-Toxoplasma from CSF

\begin{tabular}{|c|c|c|c|c|c|c|c|c|c|}
\hline & & \multicolumn{6}{|c|}{ Serologic test for IgG anti Toxoplasma } & \multirow{2}{*}{ Total } & \multirow[t]{2}{*}{$\%$} \\
\hline & & Negative & $\%$ & $\begin{array}{l}\text { Low } \\
\text { Titer } \\
\text { IgG } \\
\end{array}$ & $\%$ & $\begin{array}{l}\text { High } \\
\text { Titer } \\
\text { IgG } \\
\end{array}$ & $\%$ & & \\
\hline \multirow{3}{*}{$\begin{array}{l}\text { PCR } \\
\text { results }\end{array}$} & Positive & 4 & $7,4 \%$ & 12 & $48 \%$ & 7 & $77.8 \%$ & 23 & 26.1 \\
\hline & Negative & 50 & $17 \%$ & 13 & $56.8 \%$ & 2 & $22.22 \%$ & 65 & 73.9 \\
\hline & Total & 54 & $100 \%$ & 25 & $100 \%$ & 9 & $100 \%$ & 88 & 100 \\
\hline
\end{tabular}

Negative titer below: 11 IU, Low titer IgG anti Toxoplasma: $\geq 11-150$ IU and high titer IgG anti Toxoplasma $>150$ IU

\section{PCR examination and serologic test using ELISA}

Table 1 shows there were 23 CSF samples $(26.1 \%)$ positive by nested PCR of the B1 gene while the antiToxoplasma IgG assay showed 34 samples positive $(38,6 \%)$. Statistical analysis using Chi-Squared Test revealed a significant association $(\mathrm{p}=0.000, \mathrm{p}<0.05)$ between the two methods and a significant positive correlation between PCR and IgG results (Spearman correlation $=0.537$ and $\mathrm{p}<0.001$ )

A higher proportion of positive PCR among those with higher anti-Toxoplasma IgG; 4 out of 54 (7.4\%) samples negative for anti-Toxoplasma IgG, 12 out of 25 (48\%) samples with low anti-Toxoplasma IgG and 7 out of $9(77.7 \%)$ samples with high anti- Toxoplasma IgG. It was clear that positive PCR results had a trend to associate to higher IgG concentration, as well as the negative PCR results to very low and negative IgG titer.

\section{DISCUSSION}

In this study, the nested PCR for Toxoplasma gondii B1 gene could be alternative to diagnose Toxoplasma encephalitis in HIV patients. This study showed that positive samples showed higher titer of anti-Toxoplasma IgG.

Nested PCR was chosen as a method in this research, due to nested PCR had a respectable sensitivity. ${ }^{16-18}$ Choosing the B1 gene as a target was due to its amplification has some advantages, such as higher sensitivity than another targeting gene. ${ }^{19} \mathrm{~B} 1$ gene did not amplify DNA from any other bacterial and fungal, and its sensitivity was not changed because of different DNA count in human and increase in protein. This gene also had good gene conservation. ${ }^{20}$ Moreover, the B1 gene was the most often gene used in toxoplasmosis molecular study. ${ }^{12-14}$

From 88 samples in this study, $26.1 \%$ showed positive PCR results. This finding supported the previous experiment that the sensitivity to diagnose TE (Toxoplasma encephalitis) from CSF was about 17$100 \% .{ }^{12}$ It should be noted that PCR sensitivity was relied on some factors like the chemical and physical condition of reaction, targeting DNA concentration, choosing primer, and DNA extraction method. In this study, there was a limitation in sample volume, which was a little that could affect the DNA concentration then affect the sensitivity of the test. ${ }^{21}$ Nevertheless, this data showed that the PCR procedure in this study could be used to diagnose Toxoplasma encephalitis.

IgG was selected as the primary test to detect Toxoplasma infection because most of the HIV patients with CNS disorder originated from reactivation of past Toxoplasma infection. The previous study also confirmed the predominance of $\mathrm{IgG}$ antibodies in immune response to T.gondii. ${ }^{22}$ To assess the active infection stage, molecular detection by PCR was chosen instead of anti-Toxoplasma IgM which may not be produced due to the immunocompromised state.

IgG examination results showed a higher proportion of patients positive for anti-Toxoplasma $\mathrm{IgG}$ in comparison to the PCR result (38.6\% vs 26.1\%) suggesting that most patients suffered from Toxoplasma reactivation. This high positive percentage did not mean 
that the patients were actively infected, as a small proportion of patients with negative anti Toxoplasma IgG, showed positive PCR result. Toxoplasma serology test could fail to detect anti-Toxoplasma antibody especially in the early phase of primary Toxoplasma infection. Toxoplasma serology test could fail to detect anti-Toxoplasma antibody especially in the early phase of primary infection. This situation might be due to the antibody that was not produced until several weeks of parasitemia exceeded. ${ }^{3}$

This result is also consistent with the previous study ${ }^{4}$. That study used the same targeting gene as this study. The difference was the initial CSF volume and PCR method used. Ganiem et al. used $7 \mathrm{ml} \mathrm{CSF}$ and real-time PCR method. Another difference was the specimen used. In this study, we used CSF as samples, but the previous one used serum from HIV patients as samples.

This research came with the result that positive PCR had a trend to show higher IgG concentration. The statistical analysis was showing the significant positive correlation between PCR test and IgG status. Other investigation also showed similar results ${ }^{4}$. Nevertheless, it should be noted that in this research, several samples that show higher titer with negative PCR results.

The use of PCR will tell us the active stage of Toxoplasma infection while measuring one time anti Toxoplasma IgG will not be able to tell active infection, however we tried to find any correlation between those two tests and got $\mathrm{R}=0.537$ suggesting at some point $\mathrm{IgG}$ anti-Toxoplasma may associate to active infection however there is a need for a second test to confirm it, and PCR is currently the best. According to Vidal JE et al, all patients with cerebral toxoplasmosis presented positive result of PCR B1 (sensitivity 100\% and specificity 94.4\%) from CSF sample while poor performance was obtained when using blood samples (100\% specificity and $25 \%$ sensitivity). ${ }^{13,23}$

The limitation in this study, beside the lack of sample volume, several samples were the old collections saved for a long time. Samples in this study were part of previous study on detection of Cryptococcus in neuroAIDS and have undergone the freeze-thawing process for two times. As very small left over of the cells, this may also cause negative PCR result. This sample condition resulted in DNA degradation and caused several IgG results with high titer could not be detected by PCR. It is consistent with the previous study that reached $33.33 \%$ sensitivity from PCR. The sensitivity was increasing up to $50 \%$ if lumbal puncture was done one week before therapy and directly examined. ${ }^{21,24}$

From these results of Toxoplasma PCR examination from CSF, it was clearly stated that the high sensitivity could rule out other differential diagnosis. This test could be done to complete other supporting tests such as radiology, serology examination to diagnose active infection of Toxoplasma encephalitis.

A more complex experimental design is needed to include several HIV and AIDS centers and more samples to find the significant correlation between variables. Future study between PCR, serology of anti-Toxoplasma $\mathrm{IgG}$ and clinical information is needed and should involve several HIV AIDS centers with larger number of samples.

\section{CONCLUSION}

Nested PCR of B1 gene Toxoplasma gondii from CSF could be used to diagnose Toxoplasma Encephalitis in HIV patients. The positive PCR results tend to have higher anti-Toxoplasma IgG titer. This study showed that PCR methods to detect B1 gene was helpful for increasing the accuracy of diagnosis for Toxoplasma Encephalitis.

\section{ACKNOWLEDGMENTS}

We would thank adjunct Professor Retno Wahyuningsih who has been willing to assist in providing research samples.

\section{REFERENCES}

1. Luma HN, Tchaleu BC, Mapoure YN, Temfack E, Doualla MS, Halle MP, et al. Toxoplasma encephalitis in HIV/AIDS patients admitted to the Douala general hospital between 2004 and 2009: a cross sectional study. BMC Res Notes. 2013;6(1):146.

2. Terazawa A, Muljono R, Susanto L, Margono SS, Konishi E. High Toxoplasma antibody prevalence among inhabitants in Jakarta, Indonesia. Jpn J Infect Dis. 2003;56(27):107-9.

3. Munoz M, Liesenfeld O, Heimesaat MM. Immunology of Toxoplasma gondii. Immunol Rev. 2011;240(1):269-85.

4. Ganiem AR, Dian S, Indriati A, Chaidir L, Wisaksana R, Sturm P, et al. Cerebral Toxoplasmosis Mimicking Subacute Meningitis in HIV-Infected Patients; a Cohort Study from Indonesia. PLoS Negl Trop Dis. 2013;7(1):e1994.

5. Imran D, Estiasari R, Maharani K, Sucipto, Lestari DC, Yunus RE, et al. Presentation, etiology, and outcome of brain infections in an Indonesian hospital. Neurol Clin Pract. 2018 Oct 1;8(5):379 LP388 .

6. Robert-Gangneux F, Dardé ML. Epidemiology of and diagnostic strategies for toxoplasmosis. Clin Microbiol Rev. 2012;25(2):264-96.

7. Ferreira MS, Borges AS. Some Aspects of Protozoan Infections in Immunocompromised Patients: A Review. Mem Inst Oswaldo Cruz. 2002;97(4):44357.

8. Meira CS, Vidal JE, Costa-Silva TA, FrazattiGallina N, Pereira-Chioccola VL. Immunodiagnosis in cerebrospinal fluid of cerebral toxoplasmosis and HIV-infected patients using Toxoplasma gondii excreted/secreted antigens. Diagn Microbiol Infect Dis. 2011;71(3):279-85.

9. Alfonso Y, Fraga J, Cox R, Bandera F, Pomier O, Fonseca C, et al. Comparison of four DNA extraction methods from cerebrospinal fluid for the detection of Toxoplasma gondii by polymerase chain reaction in AIDS patients. Med Sci Monit. 2008;14(3):MT1-6.

10. Lin MH, Chen TC, Kuo TT, Tseng CC, Tseng CP. Real-time PCR for quantitative detection of Toxoplasma gondii. J Clin Microbiol. 2000;38(11):4121-5. 
11. Mesquita RT, Ziegler AP, Hiramoto RM, Vidal JE, Pereira-Chioccola VL. Real-time quantitative PCR in cerebral toxoplasmosis diagnosis of Brazilian human immunodeficiency virus-infected patients.J Med Microbiol. 2010;59(Pt 6):641-7.

12. Alfonso Y, Fraga J, Fonseca C, Jiménez N, Pinillos $\mathrm{T}$, Dorta-Contreras AJ, et al. Molecular diagnosis of Toxoplasma gondii infection in cerebrospinal fluid from AIDS patients. Cerebrospinal Fluid Res. 2009;6:2.

13. Vidal JE, Colombo FA, Penalva AC, Oliveira D, Focaccia R, Lucia V, et al. PCR Assay Using Cerebrospinal Fluid for Diagnosis of Cerebral Toxoplasmosis in Brazilian AIDS patients PCR Assay Using Cerebrospinal Fluid for Diagnosis of Cerebral Toxoplasmosis in Brazilian AIDS patients. 2004;42(10):4765-8.

14. Alfonso Y, Fraga J, Cox R, Jiménez N, Capó V, Pomier $\mathrm{O}$, et al. Conventional polymerase chain reaction for the diagnosis of neurotoxoplasmosis: comparison of three sets of primers for the B1 gene using CSF samples. Diagn Microbiol Infect Dis. 2013;75(2):150-4.

15. Derouin F, Leport C, Pueyo S, Morlat P, Letrillart B, Chene G, et al. Predictive value of Toxoplasma gondii antibody titres on the occurrence of toxoplasmic encephalitis in HIV-infected patients. ANRS 005/ACTG 154 Trial Group. AIDS. 1996 Nov;10(13):1521-7.

16. Hierl T, Reischl U, Lang P, Hebart H, Stark M, Kyme $\mathrm{P}$, et al. Preliminary evaluation of one conventional nested and two real-time PCR assays for the detection of Toxoplasma gondii in immunocompromised patients. J Med Microbiol. 2004;53(7):629-32.
17. Teixeira LE, Kanunfre KA, Shimokawa PT, Targa LS, Rodrigues JC, Domingues W, et al. The performance of four molecular methods for the laboratory diagnosis of congenital toxoplasmosis in amniotic fluid samples. Rev Soc Bras Med Trop. 2013;46(5): 584-8.

18. Vitale M. A High Sensitive Nested PCR for Toxoplasma gondii Detection in Animal and Food Samples. J Microb Biochem Technol. 2013;05(02):39-41.

19. Jones CD, Okhravi N, Adamson P, Tasker S. 18S rDNA Genes of T . Gondii in Aqueous Humor AND. Invest Ophthalmol. 2000;41(3):634-44.

20. 20. Grigg ME, Boothroyd JC. Rapid identification of virulent type I strains of the protozoan pathogen Toxoplasma gondii by PCR-restriction fragment length polymorphism analysis at the $\mathrm{B} 1$ gene. J Clin Microbiol. 2001;39(1):398-400.

21. Bastien P, Procop GW, Reischl U. Quantitative realtime PCR is not more sensitive than " conventional" PCR. J Clin Microbiol. 2008;46(6):1897-900.

22. Paulo S. Toxoplasma- Specific IgG Subclass Antibody response in Cerebrospinal Fluid. 2015;57(5):439-42.

23. Ajzenberg D, Lamaury I, Demar M, Vautrin C, Cabié A, Simon S, et al. Performance Testing of PCR Assay in Blood Samples for the Diagnosis of Toxoplasmic Encephalitis in AIDS Patients from the French Departments of America and Genetic Diversity of Toxoplasma gondii: A Prospective and Multicentric Study. 2016;1-17.

24. Cingolani A, Luca ADE, Ammassari A, Murri R, Linzalone A, Grillo R, et al. PCR detection of Toxoplasma gondii DNA in CSF for the differential diagnosis of AIDS-related focal brain lesions. 2015;45(1996):7-11. 